Laboratory, for providing computer facilities; Mrs. B. Martin and Mrs. F. M. Orbell, of the Oxford Record Linkage Study, for work on some of the tabulations; and Mrs. V. Donnelly for secretarial assistance.

R.M.A. undertook this work during a year when he was a Commonwealth Fund Senior Travelling Fellow and enjoyed the hospitality of Professor J. N. Morris at the London School of Hygiene and Tropical Medicine.

\section{REFERENCES}

Acheson, E. D. (1967). Medical Record Linkage, p. 107. London, Oxford University Press for Nuffield Provincial Hospitals Trust. Acheson, R. M. (1966). U.S. Public Health Monographs, 76, 23. Acheson, R. M. (1969). In Thrombosis, edited by S. Sherry, K. Brinkhous, E. Genton, and J. M. Stengle, p. 136. Washington, D.C., National Academy of Sciences.

Acheson, R. M., and Fairbairn, A. S. (1970). Stroke, 1. In press. Boyle, R. W., and Reid, M. (1965). Geriatrics, 20, 949.

Carroll, D. (1962). Fournal of Chronic Diseases, 15, 179.

Carter, A. B. (1963). Proceedings of the Royal Society of Medicine, 56,

483.
Conant, R. G., Perkins, J. A., and Ainley, A. B. (1965). Fournal of Chronic Diseases 18, 397.

David, N. J., and Heyman, A. (1960). Fournal of Chronic Diseases, 11, 394.

du Boulay, G. H. (1965). British fournal of Radiology, 38, 721.
Eisenberg, H., Morrison, J. T., Sullivan, P., and Foote, F. M. (1964). fournal of the American Medical Association, 189, 883.

Florey, C. Du V., Senter, M. G., and Acheson, R. M. (1967). Yale fournal of Biology and Medicine, 40, 148.

Florey, C. Du V., Senter, M. G., and Acheson, R. M. (1969). American fournal of Epidemiology, 89, 15.

1965 Registrar General's Statistical Review of England and Wales 1963, Part 1 Tables, Medical. London, H.M.S.O. 1966 Registrar General's Statistical Review of England and Wales 1964,

Howard, F. A. et al., (1963). Fournal of the American Medical Association, 183, 921.

Kannel, W. B., Dawber, T. R., Cohen, M. E., and McNamara, P. M. (1965). American Fournal of Public Health, 55, 1355.

Katz, S., Ford, A. B., Chinn, A. B., and Newill, V. A. (1966). Medi-

Kurland, L. T., Choi, N. W., and Sayre, G. P. (1967). Stroke Rehabilitation edited by W. S. Fields and W. A. Spencer, p. 3. St. Louis, Green.

Kurtzke, J. F. (1969). The Epidemiology of Cerebrovascular Disease. Berlin, Springer. Lindgren, S. O. (1958). Acta Psychiatrica et Neurologica Scandinavica,
33, 343.

Locksley, H. B. (1966). fournal of Neurosurgery, 25, 219.

Marshall, J., and Shaw, D. A. (1959). British Medical fournal, 1, 1614.

Ministry of Health and General Register Office (1967). Report on Hospital Inpatient Enquiry 1963 . London, H.M.S.O.

Ministry of Health and General Register Office (1968). Report on Hospital Inpatient Enquiry 1964. London, H.M.S.O.

Pincock, J. G. (1957). Annals of Internal Medicine, 46, 925.

Robinson, R. W., et al. (1959). fournal of the American Medical Association, 169, 1149 .

\title{
Serum Gastrin in Patients with Peptic Ulceration
}

\author{
D. J. BYRNES, ${ }^{*}$ M.R.A.C.P. ; J. D. YOUNG, $†$ L.INST.P., L.I.BIOL. ; D. J. CHISHOLM, ${ }^{*} \$ M.R.A.C.P. \\ L. LAZARUS $\ddagger$, F.R.A.C.P., F.A.A.C.B.
}

British Medical fournal, 1970, 2, 626-629

Cummary: The fasting serum level of gastrin was deter$\checkmark$ mined by radioimmunoassay in 41 normal sub;ects, 27 patients with duodenal ulceration, 12 patients with gastric ulceration, and 8 patients following "complete" vagotomy. The patients with duodenal ulceration had significantly higher serum levels of gastrin $(1 \cdot 3 \pm$ S.D. $0.7 \mathrm{ng} . / \mathrm{ml}$.) than normal subjects $(0.4 \pm$ S.D. $0.3 \mathrm{ng} . / \mathrm{ml}$.$) , patients with gastric ulceration (0.4 \pm$ S.D. $0.4 \mathrm{ng} . / \mathrm{ml}$.), or post-vagotomy patients $(0.15 \pm$ S.D. $0.2 \mathrm{ng} . / \mathrm{ml}$.$) .$

The gastrin secretion in both normal subjects and patients with duodenal ulceration was responsive to protein ingestion, but a larger incremental secretion of gastrin occurred in the latter group. Hyperglycaemia significantly suppressed the serum level of gastrin in both groups. The patients with gastric ulceration had fasting and postprandial serum gastrin levels not significantly different from normal subjects.

\section{Introduction}

Gastrin was the second hormone discovered (Edkins, 1905), but until recently no disease state had been associated with abnormalities in its secretion. It is now known that the Zollinger-Ellison syndrome (Zollinger and Ellison, 1955) is caused by pancreatic tumours secreting abnormal amounts of gastrin (Gregory et al., 1967; McGuigan and Trudeau, 1968; Odell et al., 1968), thus causing the high basal acid secretion and intractable peptic ulceration characteristic of this disease. Patients with duodenal ulceration also have an excessive basal secretion of acid (Levin et al., 1948; Woodward et al., 1949), and the demonstration (by bioassay) of increased amounts of

* Research Fellow.

+ Senior Scientific Officer.

$¥$ Director.

Garvan Institute of Medical Research, St. Vincent's Hospital, Sydney 2010

$\checkmark$ At present, Research Fellow, Royal Victuria Hospital, Montreal. gastrin in their antral tissues (Emås and Fyrö, 1964) indicates that an abnormality in gastrin secretion may also be important in the pathogenesis of this disease. In this study a sensitive radioimmunoassay has been used to determine the levels of gastrin in the sera of normal subjects and patients with peptic ulceration.

\section{Patients and Methods}

All investigations were conducted with the patients in bed in a quiet room after an overnight fast. Anticholinergics were suspended 18 hours before examination. Venous blood samples were obtained from a plastic catheter inserted into an antecubital vein 20 minutes before starting the study. The blood was allowed to clot at $4{ }^{\circ} \mathrm{C}$., then centrifuged, and the serum separated and stored at $-10^{\circ} \mathrm{C}$. until assayed. The normal subjects consisted of medical and paramedical personnel. Informed consent was obtained before beginning the study. The subjects had no personal or family history of gastrointestinal disease.

The peptic ulceration groups consisted of patients with duodenal or gastric ulceration who had been admitted to the inpatient or outpatient section of this hospital. Patients with duodenal ulceration had radiological evidence of a duodenal crater \pm scarring, while the patients with gastric ulceration had radiological \pm gastroscopic evidence of a benign gastric ulcer. Prepyloric or combined gastric and duodenal ulcers were excluded from this study. All the patients had "active" disease-that is, they had suffered a complication or had definite symptoms from their ulcer within the previous two weeks.

The post-vagotomy group had undergone bilateral truncal vagal section for duodenal ulceration six weeks to five years before examination. The gastric acid response to insulininduced hypoglycaemia was used to assess the completeness of vagotomy according to the criteria of Hollander (1948).

Fasting Levels.-Fasting venous samples were obtained 
from 41 normal subjects, 27 patients with duodenal ulceration, 5 patients with recurrence of ulceration following surgery ( 3 after incomplete vagotomy and 2 after partial gastrectomy), 12 patients with gastric ulceration, and 8 postvagotomy patients with negative gastric acid responses to insulin-induced hypoglycaemia. The Zollinger-Ellison syndrome was not suspected in any of these patients.

Protein Meal.-Seven normal subjects, 12 patients with duodenal ulceration, and 11 patients with gastric ulceration were given a standard protein meal consisting of two cubes of beef extract (Oxo) dissolved in $150 \mathrm{ml}$. of water. Venous samples were withdrawn at two-minute intervals for 16 minutes to observe the peak gastrin response and then at 20 , 30 , and 60 minutes after ingestion of the protein meal. The peak serum gastrin levels and the mean integrated gastrin response for the period $0-20$ minutes were calculated for each group.

Glucose Infusion.-A Harvard constant-infusion pump was used to infuse glucose intravenously into a forearm vein of five normal subjects and seven patients with duodenal ulceration at a rate of $0.75 \mathrm{~g} . / \mathrm{min}$. for 20 minutes. Venous samples for gastrin and glucose estimation were taken during the infusion and over the next 40 minutes.

Gastrin Assay.-Gastrin was estimated by a radioimmunoassay for this hormone described elsewhere (Young et al., 1969a). The assay used antiserum raised against pentagastrin to bind the endogenous and exogenous gastrin. Synthetic human gastrin I was used for standards and iodination. Ion-exchange resin was used to separate the "free" from "bound" iodinated hormone. Sensitivity of the assay was 0.05 ng./ml. Within assay and interassay standard deviations were 0.05 and $0.25 \mathrm{ng} . / \mathrm{ml}$. respectively at mean gastrin levels of $1.8 \mathrm{ng} . / \mathrm{ml}$. Recovery rates of 92 to $108 \%$ were obtained after the addition of 0.25 to $3.5 \mathrm{ng}$. human gastrin I to $0.5-\mathrm{ml}$. aliquots of human serum. No cross-reactivity was observed with porcine glucagon, synthetic secretin, porcine insulin, human growth hormone, human luetinizing hormone, corticotrophin, human follicle stimulating hormone, vasopressin, or angiotensin I. Pancreozymin did cross-react, but a pancreozymin-specific immunoassay (Young et al., 1969b) demonstrated that this interference in the gastrin estimation was insignificant in the fasting state and that following a maximal pancreozymin stimulus the interference was less than $0.3 \mathrm{ng}$. human gastrin I per ml.

Blood glucose levels were determined by the autoanalyser modification of the Hoffman Ferricyanide method.

\section{Results}

\section{Fasting Gastrin Levels}

Normal subjects had a mean serum gastrin level of $0.4 \pm$ S.D. $0.3 \mathrm{ng} . / \mathrm{ml}$. (Fig. 1). Patients with duodenal ulceration had a significantly $(P<0.01)$ raised mean serum level of gastrin $(1.3 \pm$ S.D. $0.7 \mathrm{ng} . / \mathrm{ml}$.) as did patients with recurrent ulceration following surgery (mean $2.1 \pm$ S.D. $1.0 \mathrm{ng} . / \mathrm{ml}$., $P<0.01)$. Repeated sampling on five duodenal ulcer patients over a seven-month period showed considerable variation in the fasting serum levels of gastrin, and these fluctuations could not consistently be related to clinical ulcer activity (Table I).

The fasting serum level of gastrin in patients with gastric ulceration was not significantly different from that of normal subjects (mean $0.4 \pm$ S.D. $0.4 \mathrm{ng} . / \mathrm{ml}$.).

Seven of the patients with "complete" vagotomy had serum gastrin levels at or below $0.2 \mathrm{ng} . / \mathrm{ml}$. and the remaining patient had a level of $0.6 \mathrm{ng} . / \mathrm{ml}$. The mean serum level of gastrin in these patients $(0 \cdot 15 \pm$ S.D. $0.2 \mathrm{ng} . / \mathrm{ml}$.) was significantly lower than in either the untreated duodenal ulceration patients $(P<0.01)$ or normal subjects $(P<0.05)$.

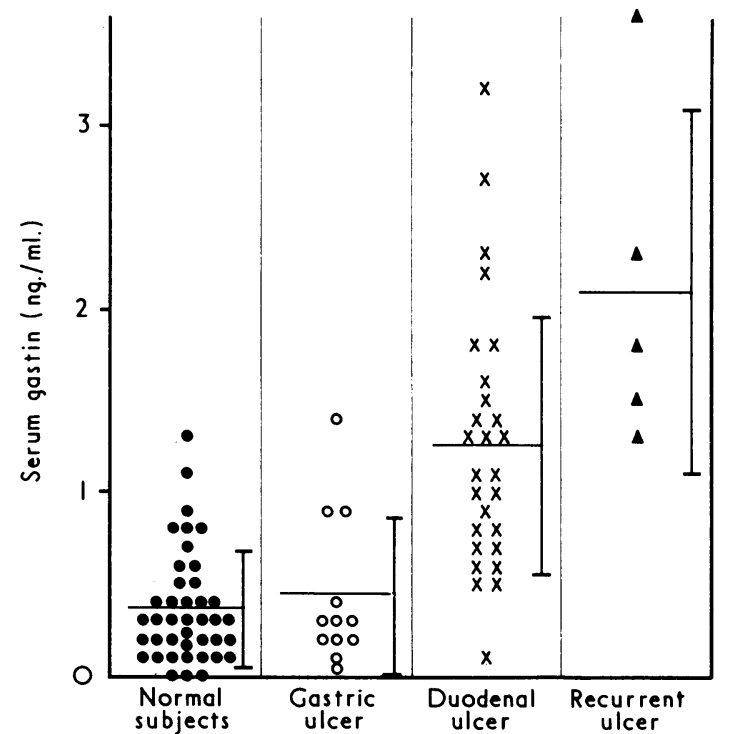

Fig. 1.-Fasting serum levels of gastrin in normal subjects and in patients with duodenal, gastric, or recurrent ulceration following surgery. vertical bar.

TABLE I.-Fasting Serum Levels of Gastrin (ng./ml.) Observed in Five TABLE I.-Fasting Serum Levels of Gastrin (ng./ml.) Observed in Five
Patients with Duodenal Ulceration During Episodes of Clinical Ulcer
Activity $(+)$ and periods of Quiescence (-)

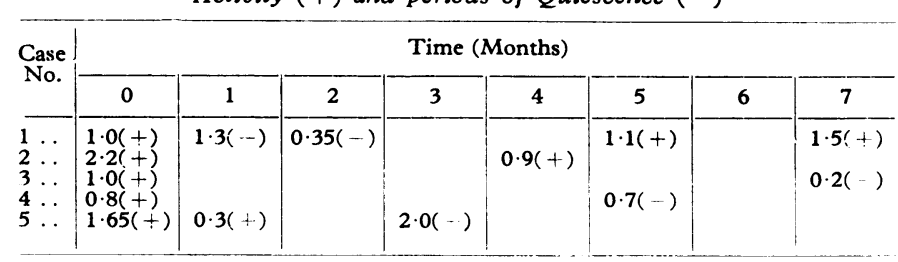

\section{Gastrin Response to Protein Meal}

Normal subjects had a mean peak serum gastrin level of $4.7 \pm$ S.D. $3 \cdot 1 \mathrm{ng} / \mathrm{ml}$. occurring 6 to 20 minutes after ingestion of the meal. The serum gastrin level then fell to within the normal fasting range by 30 minutes (Fig. 2).

The patients with duodenal ulceration had a significantly $(\mathrm{P}<0.05)$ raised mean peak gastrin level $(14.9 \pm$ S.D. 10.4 ng. $/ \mathrm{ml}$.) after the ingestion of protein. The integrated gastrin response from 0 to 20 minutes (Table II) was also significantly $(P<0.01)$ greater in the patients with duodenal ulceration $(126 \cdot 2 \pm$ S.D. $82 \cdot 7 \mathrm{ng}$. $\mathrm{min} . / \mathrm{ml}$.) than in the normal subjects (40.8 \pm S.D. $17.1 \mathrm{ng}$. $\mathrm{min} . / \mathrm{ml}$.).

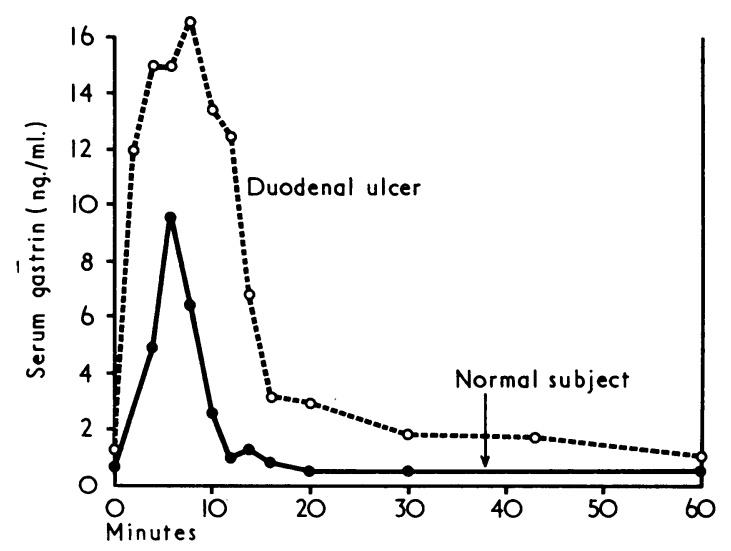

FIG. 2.-Representative serum gastrin responses following the ingestion of protein in a normal subject and in patients with duodenal ulceration. 
TABLE II.-Integrated (0-20 min.) Serum Gastrin Responses Following the Ingestion of Protein in Normal Subjects and in Patients with Duodenal or Gastric Ulceration

\begin{tabular}{|c|c|c|c|}
\hline Group & No. & $\begin{array}{c}\text { Integrated Gastrin Response } \\
0-20 \mathrm{~min} \text {. (Mean } \pm \text { S.D.) }\end{array}$ & $\begin{array}{l}\text { Serum Gastrin Level } \\
\text { at } 20 \mathrm{~min} \text {. (Mean } \pm S . D \text { ) }\end{array}$ \\
\hline $\begin{array}{l}\text { Normal i. } \quad . . \\
\text { Gastric ulcer } \\
\text { Duodenal ulcer .. }\end{array}$ & $\begin{array}{r}6 \\
10 \\
13\end{array}$ & $\begin{array}{r}40.8 \pm 17.1 \mathrm{ng} \cdot \mathrm{min} . / \mathrm{ml} . \\
45.8 \pm 52.4 \mathrm{ng} . \mathrm{min} . / \mathrm{ml} . \\
126.2 \pm 82.7 \text { ng. } \mathrm{min} . / \mathrm{ml} . \dagger\end{array}$ & $\begin{array}{l}1.3 \pm 0.78 \mathrm{ng} / \mathrm{ml} \\
0.5 \pm 0.67 \mathrm{ng} / \mathrm{ml} . \\
2.9 \pm 3.28 \mathrm{ng} / \mathrm{ml} .\end{array}$ \\
\hline
\end{tabular}

*Not significantly different from normal subjects: $t=0.21,0.9>\mathrm{P}>0.8$.

+ Significantly higher than normal subjects and gastric ulcer patients: $t=2.4$ and 2.6 respectively, $0.05>P>0.01$.

After the ingestion of protein the patients with gastric ulceration had a mean integrated gastrin response (45.8 \pm 52.4 ng. $\mathrm{min} . / \mathrm{ml}$.) which was significantly lower $(P<0.01)$ than in the duodenal ulcer patients, but not significantly different from that of the normal subjects, Furthermore, after 20 minutes the mean gastrin level had fallen to a level $(0.5 \pm$ S.D. $0.67 \mathrm{ng} . / \mathrm{ml}$.) significantly $(\mathrm{P}<0.05)$ below the normal and close to the original fasting level, showing that there was no prolonged secretion of gastrin in these patients after the ingestion of a liquid protein meal.

\section{Gastrin Response to Intravenous Glucose}

The level of blood glucose in all subjects was about doubled by the glucose infusion. A significant $(P<0.01)$ decrease in the serum gastrin level was observed in both the normal subjects $(0.53 \pm$ S.E. 0.4 to $0.05 \pm$ S.E. $0.25 \mathrm{ng} . / \mathrm{ml}$. $)$ and patients with duodenal ulceration $(1.7 \pm$ S.E. 0.3 to $0.4 \pm$ S.E. $0.1 \mathrm{ng} . / \mathrm{ml}$.) during the hyperglycaemic phase (Figs. 3 and 4 ). Three normal subjects and two patients with duodenal ulceration had no change in serum gastrin concentration during the infusion of saline alone over a 60 -minute period.

\section{Discussion}

Most patients with duodenal ulceration and all patients with a recurrence of ulceration following surgery had raised serum levels of gastrin $(>1.0 \mathrm{ng} . / \mathrm{ml}$.$) . Nevertheless, 12$ patients ( $46 \%$ of the duodenal ulceration group) had levels within the normal range. Repeated gastrin estimations showed that there are considerable fluctuations in the serum levels of gastrin in patients with duodenal ulceration (Table I). Therefore probably some of the patients with normal gastrin levels when first examined would have hypergastrinaemia at other times, and a study is in progress to examine this theory. The pronounced variation in serum gastrin may be one of the main factors in the reported variations in basal gastric acid secretion (Littman, 1962; Sun et al., 1965).

\section{Fiqure 3}

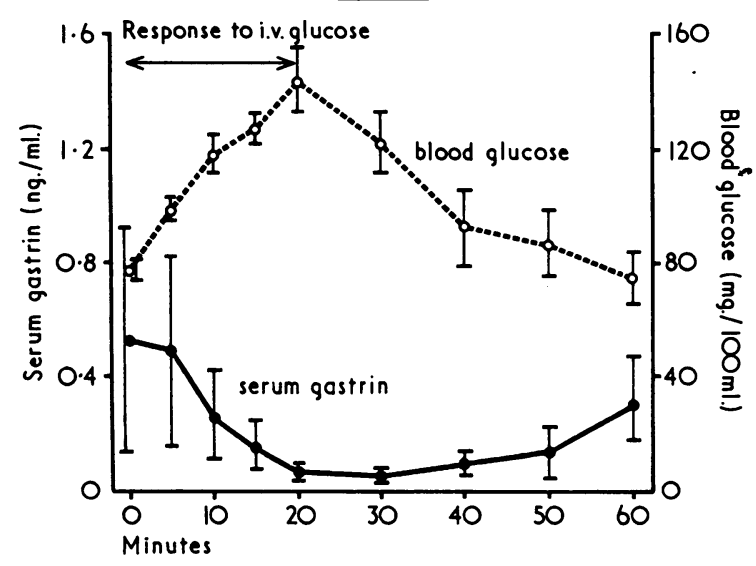

The serum gastrin response following the ingestion of protein was more pronounced in the duodenal ulcer patients who were secreting larger amounts of gastrin than in normal subjects. The excessive gastrin release may be due to the increased stores of gastrin which have been described in this disease (Emås and Fyrö, 1964) or to a facilitated release of gastrin, possibly due to an increased baseline vagal tone which has "primed" the gastrin-secreting cells.

Investigation in this laboratory into the augmented insulin release by gut hormones led to the coincidental finding of the prompt suppression of serum gastrin in normal subjects by intraduodenal or intravenous glucose (Kraegen, 1969), whereas the oral ingestion of $50 \mathrm{~g}$. of glucose resulted in an initial transient rise in serum gastrin which was then followed by suppression of the serum gastrin below the fasting level during the hyperglycaemic phase. In this paper it has been shown that the hypergastrinaemia associated with duodenal ulceration is also suppressed by hyperglycaemia. The hyperglycaemic suppression of gastrin secretion is unlikely to be a direct effect of glucose on the gastrin-secreting cells because the oral ingestion of glucose produces an initial rise in serum gastrin. The observation (Anand et al., 1962) that hyperglycaemia decreases the neural activity in the hypothalamic "feeding centre" indicates the likelihood of a central mode of action of glucose on gastrin secretion, possibly mediated by a decrease in vagal "tone." The low serum level of gastrin in patients following "complete" vagotomy supports this concept.

Physiologically, levels of blood glucuse may be important as a feedback system regulating gastric secretion according to appetite and the absorption of digestive products; hypoglycaemia has been shown to stimulate the release of gastrin (Byrnes et al., 1969), and probably hyperglycaemia facilitates the local inhibitory effect of acid on gastrin release in the post-digestive period. Similarly, since protein is a potent stimulus for gastrin release it would be expected that there may also be a feedback system whereby the postprandial hyperaminoacidaemia would suppress further gastrin release, but preliminary studies with arginine infusions have not supported this theory.

No abnormality of gastrin secretion in either the fasting or the stimulated state, was observed in patients with gastric ulceration. Notably there was no prolonged postprandial release of gastrin which has been suggested (Dragstedt, 1965) to be a factor in the pathogenesis of gastric ulceration. Studies of serum gastrin in patients with peptic ulceration showed that these levels were raised in patients with duodenal but not gastric ulceration and that the hypergastrinaemia associated with duodenal ulceration was abolished by vagotomy. It has also been shown that gastrin secretion is

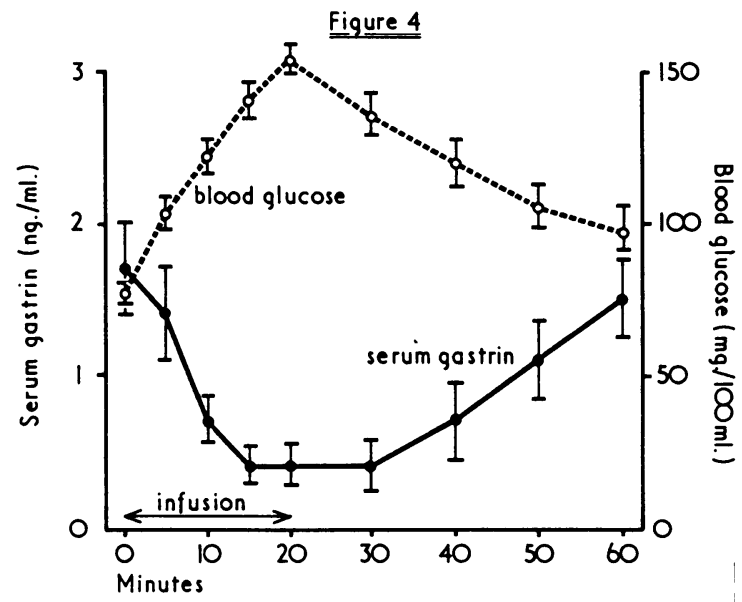

FIG. 3.-Serum gastrin response in 5 normal subjects during the induction of hyperglycaemia (mean \pm S.E.). Fig. 4.-Serum gastrin response in 7 patients with duodenal ulceration during the induction of hyperglycaemia (mean \pm S.E.). 
responsive to changes in blood glucose, and evidence has been provided that this action is probably mediated by the hypothalamus, constituting a physiological "feedback" mechanism.

We thank the physicians and surgeons of St. Vincent's Hospital for referring patients under their care to this study, and Mr. F. B. Griffiths and Miss S. Whitington for performing blood glucose estimations.

\section{REFERENCES}

Anand, B. K, Chhina, G. S, and Singh, B. (1952). Science, 138, 597. Byrnes, D. J., Young, J., and Lazarus, L. (1969) Proceedings of the Australian Society for Medical Research, 2, 282

Dragstedt, L. R. (1965). Lancet, 1, 816.

Edkins, J. S. (1905). Proceedings of the Royal Society Series B, 76, 376 Emås, S., and Fyrö, B. (1964). Gastroenterology, 46, 1.
Gregory, R. A., Grossman, M. I., Tracy, H. J., and Bcntley, P. H. (1967). Lancet, 2, 543.

Hollander, F. (1948). Gastroenterology, 11, 419.

Kraegen, E. W. (1969). Ph.D. Thesis, N.S.W. University Australia.

Levin, E., Kirsner, J. B., Palmer, W. L., and Butler, C. (1948). Gastroenterology, io, 952 .

Littman, A. (1962). Gastroenterology, 43, 166

McGuigan, J. E., and Trudeau, W. L. (1968). New England fournal of Medicine, 278, 1308.

Odell, W. D., Charters, A. C., Davidson, W. D., and Thompson, J. C. (1968). Fournal of Clinical Endocrinology and Metabolism, 28, 1840.

Sun, D. C. H., Shay, H., and Ciminera, J. L. (1965). Fournal of the American Medical Association, 158, 713 .

Woodward, E. R., Hayes, P. V., Tovee, E. B., and Dragstedt, L. R. (1949) Archives of Surgery, 59, 1191.

Young, J. D., Lazarus, L., Chisholm, D. J., and Atkinson, F. F. V. (1969a). Fournal of Nuclear Medicine. 10, 743.

Young, J. D., Byrnes, D. J., Chisholm, D. J., Griffiths, F. B., and Lazarus, L. (1969b). Fournal of Nuclear Medicine, 10, 746.

Zollinger, R. M., and Ellison, E. H. (1955). Annals of Surgery, 142, 709.

\title{
Survey of Workers Exposed to Dusts Containing Derivatives of Bacillus Subtilis
}

\author{
M. GREENBERG ${ }^{*}$ M.B., M.R.C.P. ; JUDITH F. MILNE, $†$ M.B., M.R.C.P. ; A. WATT, ${ }^{*}$ M.B., D.P.H., D.I.H.
}

\begin{abstract}
ummary: In a survey of 121 workers exposed to dusts containing derivatives of Bacillus subtilis, mainly proteolytic enzymes, skin tests showed evidence of sentiztaion was higher among "atopic" subjects-16 out of tization was higher among "atopic" subjects-16 out of $25(64 \%)$-than among "non-atopic" subjects-32 out of $96(33 \%)$. Reduced ventilatory capacity was found in $44 \%$ of sensitized workers compared with $14 \%$ of those not sensitized.
\end{abstract}

\section{Introduction}

The introduction of washing powders containing derivatives of Bacillus subtilis-mainly proteolytic enzymes-has been associated with a health hazard to workers involved in their manufacture. Previous investigators have shown that these materials are allergenic and on inhalation can sensitize exposed subjects, some of whom develop respiratory symptoms (Flindt, 1969; Pepys et al., 1969). The present study was designed to survey all the workers exposed to such enzyme dusts at one detergent factory. Assessments were made by questionary, spirometry, and skin tests, with serological tests in selected subjects.

Early in June 1967 B. subtilis derivative was introduced into a washing-powder product, following which five workers complained of respiratory symptoms. Changes in plant design were made, and it was thought that the hazard had been eradicated as no further complaints were recorded for over six months. The survey was carried out, with the co-operation of management and workers, to test the effectiveness of the engineering measures.

The $B$. subtilis derivative concentrate in impervious $50-\mathrm{kg}$. paper sacks was taken from store as required and unloaded into metal bins in a room used exclusively by one man provided with air-line helmet and protective clothing. After use the room was hosed down. The bins were transported to an outside cabinet, where they were tipped into a chute from which the material was transported mechanically to the top of

\footnotetext{
* H.M. Factory Inspectorate (Medical Branch), 1-13 Chepstow Place,

$T$ Lecturer, Department of Clinical Immunology, Institute of Diseases of the Chest, London S.W.3.
}

the mixing building. Packing was by an automatic machine equipped with exhaust ventilation situated in a room with tiled walls and floor which were regularly washed down.

The process was an intermittent one, so that during 1968, for example, a total of only 41 days had been spent using $B$. subtilis derivative in manufacture. The departmental labour force consisted of 46 women employed on two shifts and 65 men working three shifts. Others considered to be at risk were supervisors and maintenance men. The intensity and duration of exposure varied considerably within the group and could not be documented adequately in retrospect. A total of 121 workers were fully examined in May 1969. One worker was unable to complete the investigation so was omitted from the analysis. Eight who were unavailable in May were examined in September 1969, and their results are considered separately. It is thought that very few workers were missed on both occasions.

\section{Subjects and Methods}

The survey team consisted of investigators trained and well practised in the techniques of assessment used. Each of the 121 workers examined was seen on a single occasion during his working hours, so that assessments were made at various times of day and night.

Questionary.-The M.R.C. Questionary on Respiratory Symptoms, 1960, was used, with supplementary questions concerning complaints noted in previous studies of workers handling enzyme powders. The complaints included nasal symptoms (stuffiness or running of the nose, sneezing attacks, nose bleeding), chest symptoms (breathlessness, cough, chest pain), and general symptoms (shivering attacks, faintness, malaise).

Spirometry.-Measurements of forced expiratory volume in one second (F.E.V.1) and forced vital capacity (F.V.C.) were made with the McDermott dry spirometer, the mean of three technically satisfactory recordings being taken, after twc practice attempts.

Skin tests were carried out by the prick technique; beforf testing, the skin was rinsed with water to remove any materials the worker had been handling. Weal sizes were recorded 15 minutes after testing. A weal of $1 \mathrm{~mm}$. diameter or greater 